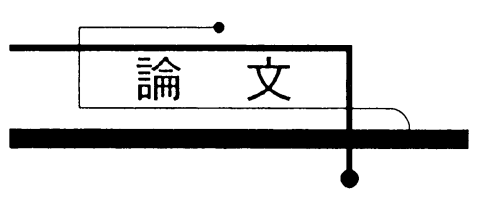

\title{
フェーズフィールド法を用いた 水流中の二酸化炭素気泡の数値シミュレーション*
}

\author{
Numerical Simulation of Carbon-dioxide Bubbles in Water Flow Using a Phase-field Method
}

\author{
木下 輝 彦*** \\ KINOSHITA Teruhiko
}

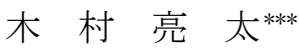 \\ KIMURA Ryota
}

\author{
萩 原 良 道 ${ }^{* *}$
}

HAGIWARA Yoshimichi

\begin{abstract}
We carried out two-dimensional numerical simulation for downward Poiseulle water flow with a carbon-dioxide bubble or multiple carbon-dioxide bubbles in a vertical channel. A phase-field method was used for capturing the interface. The concentration equation including the phase-field function and the time evolution equation of the phase-field function including the velocity field were solved simultaneously by using Graphics Processing Units. The results showed that a bubble in the offset position moved away from the left-hand side wall, while it was rising, due to the lift force. This motion causes the development of asymmetrical, complicated structure of wake flow. Then, the bubble moved towards the wall due to the change in the flow velocity field. These time changes in the wake flow enhance the diffusion and absorption of carbon dioxide in flow. In the case of four bubbles, the decreasing rate of bubble mass is higher than that for a single bubble. This is partly because of the difference in the interface length, and partly because of the renewals both of the concentration boundary layer and the wake-flow structure caused by the impact of bubble coalescence.
\end{abstract}

Keywords: Carbon dioxide, Bubbles, Laminar flow, Phase-field method, Concentration

\section{1. 緒 言}

近年、地球温暖化の抑制策の有望な一つとして、 二酸化炭素の回収・貯蔵技術 (Carbon Capture Storage 技術）の確立が注目を浴びている。この 技術の中核をなす二酸化炭素の回収手段として、 物理吸収法・化学吸収法・物理吸着法などが検討 された[1]。物理吸収法の代表例として、水に二酸 化炭素ガスを溶解させる方法がある。この手法は、 水を流すことにより二酸化炭素ガスの吸収と輸 送を同時に行えるという優れた点がある。水は安 価で安全な溶媒であるという利点も大きい。

気泡から水中への二酸化炭素の溶解に関して、 これまで多くの研究が行われてきた。実験的研究 の例として、Takemura and Yabe[2]は静止水中を上
昇する球形二酸化炭素気泡の溶解速度を評価し た。阿部ら[3]および Horikane ら[4]は、それぞれ 鉛直管内および鉛直ダクト内の二酸化炭素一水 系において、気泡体積の減少量の計測を行った。 液中の物質輸送を伴う気泡流に関する数值シミ ュレーションは最近増えてきており、例えば界面 形状を固定した研究[5]、界面の時空間変化の予測 に Volume-of-Fluid (VOF)法を用いた研究[6 - 8]、 Front tracking 法を用いた研究[9]、拡散界面モデル の一例である Level set 法を用いた研究[10, 11]な どがある。これらの研究の結果は、液中の物質輸 送の予測の有効性を示している。しかしながら、 一部を除いて気体の溶解による気泡の収縮を扱 っていない、物性值が実際の気体や液体のそれら

* 2015.11.22 受付

** 京都工芸繊維大学機械工学系 $\overline{7} 606-8585$ 京都市左京区松ヶ崎御所海道町

TEL: (075)724-7324 FAX: (075)724-7300 E-mail: yoshi@kit.ac.jp

*** 京都工芸繊維大学大学院工芸科学研究科 
と異なる、無次元数が明示されていないあるいは パラメータとして扱われている、などの問題があ る。したがって、実際の現象の予測や実験結果と の比較が困難である。さらに、微細流路内のテー ラー気泡流は扱われているが、本研究で扱う気泡 を伴うチャネル内水流が扱われていない。

そこで本研究では、文献[4]で扱われた矩形ダク 卜内水流中の二酸化炭素気泡の挙動の解明を最 終目的として、拡散界面モデルの一種である phase-field 法を用いて界面における溶解・揮発を 伴う二酸化炭素気泡の変形と縮小を表現し、同時 に Navier-Stokes 方程式を解くことにより、溶解を 伴う二酸化炭素気泡-水二相流の数值シミュレー ションを試みる。 phase-field 法は、固体の融解や 凝固現象における固液界面の挙動を phase-field変 数を用いて予測する手法として、開発され発展し てきた。近年 phase-field 法を用いた気液二相流の 予測に関する研究が行われてきている。Liu and Shen [12]は、気泡変形や二気泡の接近の二次元計 算を行った。Shu and Yang [13]は、格子ボルツマ ン法により phase-field 変数の式を解いて、静止水 中を上昇する空気泡の終端速度が実験值とよく 一致することを示した。高田と冨山[14]は、加熱 平板上での気泡核生成と等温物体のキャビテー ション後流の二次元計算を行い、相变化二相流へ の phase-field 法の適用可能性を示した。しかしな がら、著者らが知る限り、 phase-field 法を用いた 水流中の二酸化炭素気泡の溶解の予測はない。

本研究では、Navier-Stokes 方程式、phase-field 変数の支配方程式、および液体中の二酸化炭素濃 度の支配方程式を解き、二酸化炭素気泡を含む鉛 直チャネル内下向きポワズイユ流の数值シミュ レーションを行う。

\section{2. 計算手法}

\section{1 仮定}

二次元流れを対象とした。二酸化炭素気泡の溶 解速度は、濃度の拡散速度に依存すると仮定した。

\section{2 支配方程式}

水流の支配方程式として、連続の式、および以 下の NS 式を用いた。

$$
\rho\left\{\frac{\partial \vec{u}}{\partial t}+(\vec{u} \cdot \nabla) \vec{u}\right\}=-\nabla P+\mu \nabla^{2} \vec{u}+\vec{h}+\phi a^{2} \nabla \nabla^{2} \phi
$$

ここで $\vec{h}=\left(\rho-\rho_{l i q}\right) \vec{g}$ は浮力項であり、右辺第 4 項は連続的に変化する phase-field 変数 $\phi(\phi=1$ : 気 相、 $\phi=0$ : 液相、 $\lambda<\phi<1-\lambda$ :界面、 $\lambda=0.1$ とした $)$ によって表される表面張力項である[15]。 $a$ は勾 配係数、 $\mu$ は粘性係数、 $\rho$ は密度、 $t$ は時間、 $\vec{u}$ は 速度を表す。

二酸化炭素の溶解・揮発は、 $\phi$ の時間発展方程 式を解いて求めた。このとき、一般的な非保存系 に対する Allen-Cahn 方程式ではなく、保存系かつ 式(1)右辺第 4 項に含めたために不要になる表面 張力項を除いた、以下の修正 Allen-Cahn 方程式 $[15,16]$ を解いて求めた。

$$
\begin{gathered}
\frac{\partial \phi}{\partial t}=M_{\phi} a \nabla\left\{\left(a-\sqrt{2 W} \frac{\phi(1-\phi)}{|\nabla \phi|}\right) \nabla \phi\right\} \\
-M_{\phi}\left(f_{\text {gas }}-f_{\text {liq }}\right) \frac{d p}{d \phi}-\nabla(\phi \vec{u}) \\
p=\phi^{3}\left(10-15 \phi+6 \phi^{2}\right)
\end{gathered}
$$

ここで $W$ はダブルウェルポテンシャル、 $p$ は勾配 関数を表す。気液のポテンシャルエネルギー差は、 理想気体の化学ポテンシャルエネルギーの式[17]、 溶液中の溶質の化学ポテンシャルエネルギーの 式[18]、および水に溶解する二酸化炭素のモル分 率が極めて低いことから、次式で表される[19]。

$$
f_{\text {gas }}-f_{\text {liq }}=-\frac{R}{v_{m}} T \ln \left(\frac{c_{\text {liq }}}{c_{\text {sat }}}\right)
$$

$R$ は気体定数、 $v_{m}$ は気体のモル体積、cliq は溶存 濃度、 $c_{s a t}$ は飽和濃度であるり、ヘンリーの法則 より次式で表される。

$$
c_{\text {sat }}=\frac{P_{\text {gas }}}{K} c_{\text {liq }}
$$

式(2)の $a 、 W 、 M_{\phi}$ は以下の式[20]により定めた。

$a=\sqrt{\frac{3 \delta \gamma}{b}}, W=\frac{6 \gamma b}{\sqrt{\delta}}, M_{\phi}=\frac{b}{3 \delta} M$

ここで $\delta$ は界面幅、 $\gamma$ は界面エネルギー、 $M$ はモ ビリティである。なお、 $b=2 \tanh ^{-1}(1-2 \lambda)$ の関係 が成り立つ。 $a$ の式は、一次元平衡状態の界面に おいて気液の化学ポテンシャルが等しいことか ら、式(2)の右辺第 1 項 $=0$ の関係が成り立ち、 
その関係式を積分して得られる。Wの式は、界面 における気液化学ポテンシャルを 0 としたとき に、 $\gamma$ はポテンシャルエネルギーと $\phi$ の勾配エネ ルギーの和の積分值と等しくなることより得ら れる。 $M_{\phi}$ の式は、平衡状態かつ一定速度で移動 する界面を仮定すると、その速度は $M$ と気液化 学ポテンシャル差の積で表わされること、式(2) の左辺は空間微分で書き換えられることより得 られる。

濃度に関する時間発展には、文献[21]の式をさ らに変形した次式を用いた。

$$
\begin{aligned}
\frac{\partial c_{l i q}}{\partial t}= & D \nabla^{2} c_{l i q}+M_{\phi}\left(f_{\text {gas }}-f_{\text {liq }}\right) \frac{d p}{d \phi}\left(c_{\text {gas }}-c_{\text {liq }}\right) \frac{d \phi}{d t} \\
& -\nabla \cdot\left(c_{\text {liq }} \vec{u}\right)
\end{aligned}
$$

式(7)の $D$ は水中溶存二酸化炭素の拡散係数を、 右辺第 2 項は気泡溶解に伴う溶存二酸化炭素量 の変化を、右辺第 3 項は流れによる移流をそれぞ れ表す。

\section{3 計算スキーム}

プログラムの並列化を行って、Graphics Processing Units (GPU) を用いた高速計算を実現 した。ソフトウェア CUDA (Compute Unified Device Architecture） [22]を用いて、計算プログラ ムを開発した。

GPU に適した Red-Black HSMAC 法[23]を用い た緩和計算により、圧力ポアソン式を解いた。 NS 式の移流項の離散化には補間法を用いた二次 精度中心差分を用いた[24, 25]。時間項の離散化に は二次精度 Adams-Bashforth 法を用いた。

phase-field 変数の支配方程式および濃度の支配 方程式の移流項の離散化には、A 型 CIP 法[26]を 用いた。移流項外の空間項離散化には二次精度中 心差分を用いた。時間項の離散化には 2 次精度 Adams-Bashforth 法を用いた。

二次元キャビティー流れを対象とし、格子点数 を $64^{2}, 128^{2}, 256^{2}, 512^{2}$ と増やして GPU の有効性 を確認した[19]。その結果、GPUを使用しなかっ た場合と比較して、計算時間はそれぞれ $1 / 2.3$, 1/8.5, 1/23, 1/38 に減少した。したがって、GPUの 有効性が確認された。

\section{4 計算領域と境界条件}

Fig. 1 に計算領域を示す。鉛直チャネルの幅は、 文献[4]と同じ $10 \mathrm{~mm}$ とした。鉛直方向は $16 \mathrm{~mm}$

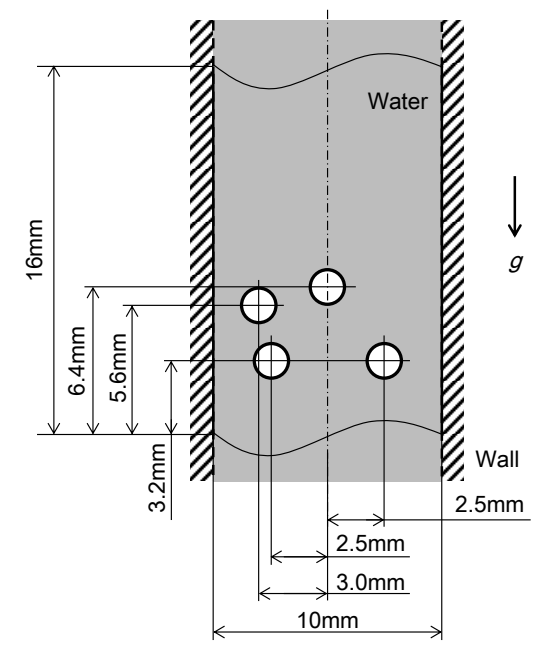

Fig. 1 Initial location of four bubbles.

とした。対称軸上に原点を取り、鉛直上向きに $x$ 軸を、チャネル壁直角方向に $y$ 軸を定めた。 $x$ 軸 方向には周期境界条件を与え、壁面上は滑りなし 条件を与えた。

\section{5 計算条件}

Table 1 に支配型方程式の離散化のための格子 間隔と時間間隔を示す。あわせて、フェーズフィ 一ルド変数の支配方程式中の定数を定める式(6) に必要な、界面モビリティと界面厚さの值を示す。 Table 2 には、用いた物性值、および設定した圧 力と温度を示す。この表より、密度比 $\rho_{\text {gas }} / \rho_{\text {liq }}$ は 0.00178 となり、粘性係数比 $\mu_{\text {gas }} / \mu_{\text {liq }}$ は 0.0148 と なる。なお、モルトン数は $2.63 \times 10^{-11}$ であった。

実際の物性值を用いるため、シュミット数は 511 となる。このようにシュミット数が高い場合 には、界面近傍の濃度境界層が極めて薄く、濃度 の時間発展方程式を高い精度で解くには、界面近 傍の格子解像度を上げたり、境界層近似を施した りする必要性が指摘されている[9]。境界層近似は、 文献[9]で対象とした高モルトン数液体中の変形 しにくい気泡の場合には有効である。しかしなが ら、水流の速度勾配により生じる揚力を受けつつ 変形し搖動運動する気泡の場合には、界面近傍の 速度場・濃度場は著しく変動するため、境界層近 似は妥当ではない。また、気泡の変形や搖動運動 が引き起こす疑似乱れによる「乱流物質拡散」は、 界面近傍や気泡後流においては分子拡散よりも はるかに優勢である。乱流シュミット数の議論を 
踏まえ、「乱流物質拡散」は疑似乱れによる「乱 流運動量拡散」と同程度であると仮定すると、濃 度場を得るための格子解像度は速度場のための 格子解像度と同程度でよいことになる。これらの ことを考慮して、本研究では、高い格子解像度と 境界層近似は用いなかった。

Table 1 Discretization parameters and interface mobility and thickness

\begin{tabular}{lll}
\hline 格子数 & $N x, N y$ & 640,400 \\
格子間隔 & $\Delta x, \Delta y$ & $0.025 \mathrm{~mm}, 0.025 \mathrm{~mm}$ \\
時間間隔 & $\Delta t$ & $1.0 \times 10^{-7} \mathrm{~s}$ \\
\hline 界面モビリティ & $M$ & $5.0 \times 10^{-7}$ \\
界面厚さ & $\delta$ & $0.3 \mathrm{~mm}(=12 \Delta x)$ \\
\hline
\end{tabular}

Table 2 Physical properties, pressure and temperature

\begin{tabular}{lrll}
\hline 気体定数 & $R$ & $8.31 \mathrm{~J} /(\mathrm{mol} \cdot \mathrm{K})$ & {$[27]$} \\
ヘンリー定数 & $K$ & $165.8 \mathrm{MPa}$ & {$[28]$} \\
拡散係数 & $D$ & $1.964 \times 10^{-9} \mathrm{~m}^{2} / \mathrm{s}$ & {$[28]$} \\
理想気体のモル体積 & & $24.8 \times 10^{-3} \mathrm{~m}^{3} / \mathrm{mol}$ & {$[27]$} \\
二酸化炭素密度 & $\rho_{g a s}$ & $1.77 \mathrm{~kg} / \mathrm{m}^{3}$ & \\
二酸化炭素粘性係数 & $\mu_{g a s}$ & $1.49 \times 10^{-5} \mathrm{~kg} /(\mathrm{m} \cdot \mathrm{s})$ & \\
\hline 水の分子量 & & $18.01 \mathrm{~g} / \mathrm{mol}$ & {$[29]$} \\
界面自由エネルギー & $\sigma$ & $7.20 \times 10^{-2} \mathrm{~J} / \mathrm{m}^{2}$ & {$[29]$} \\
水の密度 & $\rho_{l i q}$ & $997 \mathrm{~kg} / \mathrm{m}^{3}$ & \\
水の粘性係数 & $\mu_{l i q}$ & $1.00 \times 10^{-4} \mathrm{~kg} /(\mathrm{m} \cdot \mathrm{s})$ & \\
\hline 圧力 & $P$ & $0.1 \mathrm{MPa}$ \\
温度 & $T$ & $298.15 \mathrm{~K}$ & \\
\hline
\end{tabular}

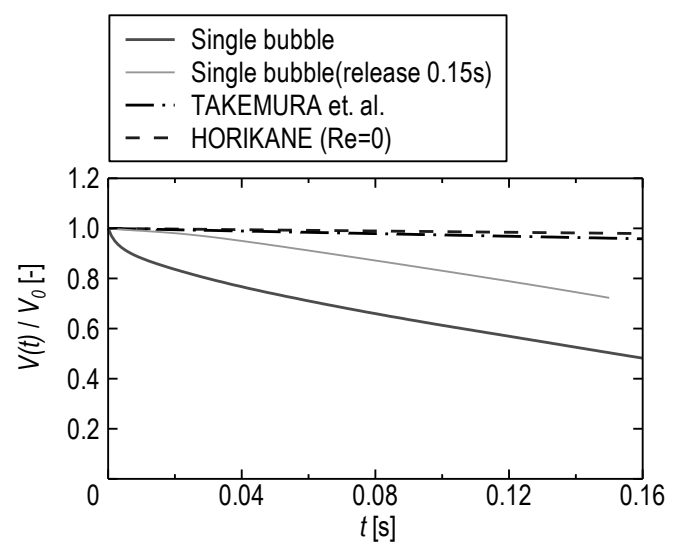

Fig. 2 Time changes in $\mathrm{CO}_{2}$ bubble volume.
チャネル幅と平均速度に基づく水流のレイノ ルズ数は、 $0,100,1000$ とした。初期の気泡径は 1 個の場合は $3.0 \mathrm{~mm} 、 4$ 個の場合は $1.5 \mathrm{~mm}$ とした。 初期の気泡位置は、1 個の場合には対称軸上ある いは対称軸と左側の壁の中央（以下オフセットと 略す）とし、4 個の場合はFig. 1 の位置とした。 なお、 1 個の場合における、初期の気泡に関する エトベス数は 1.22 であった。

\section{3. 結果と考察}

\section{1 静止水中の気泡}

Fig. 2 に、初めに対称軸上に置かれた二酸化炭 素気泡が静止水中を上昇する間の体積の時間変 化を示す。気泡体積は、 $\phi$ の值の総和により求め た。なお、気泡レイノルズ数は 60 以下であった。 図には、気泡レイノルズ数が 93 以下である Takemura and Yabe[2]の実験結果、および幅 10mm の鉛直チャネルを用いた Horikane ら[4]の実験結 果（気泡レイノルズ数は 1000 以下）も示されて いる。本計算結果は、 $t<0.01 \mathrm{~s}$ 間に急激な体積の 減少を示すものの、その後減少は鈍り、 $t>0.04 \mathrm{~s}$ では減少率がほぼ一定になることを示す。

この傾向は、初めから一定の減少を示す実験結 果と異なる。その原因として、計算条件と異なる 実験条件 (3 次元気泡、水中の溶質、静水圧)、 および計算における初期条件、周期境界条件、数 值粘性が考えられる。本研究では、これらの要因 のうち、初期条件に注目する。実験の場合には、 測定開始時において界面近傍濃度境界層と後流 構造は発達していたと考えられるが、本計算では、 初期条件において両者とも未発達状態とした。濃 度境界層と後流をともに発達させた状態から計 算を開始することは困難である。そこで、最初の $0.15 \mathrm{~s}$ 間は気泡に㗢く浮力を強制的に 0 として、 その間に濃度境界層の発達を促し、その後浮力を 考慮して後流を発達させた計算を行った。その結 果をFig. 2 に示す。図より、この計算結果は、濃 度境界層を発達させなかった計算結果より、実験 結果に近いことがわかる。それでもなお、時間の 経過とともに差がやや広がる。この原因としては、 二次元計算、数值粘性などが考えられるが、今後 の検討課題とする。

さらに、文献[7]に記載のシャーウッド数の定義 式を 2 次元気泡用に変形した、次式で定義される シャーウッド数を求めた。 


$$
S h=\frac{k \cdot d}{D}=\frac{\Delta S}{L \cdot\left(c_{\infty}-c_{\mathrm{int}}\right) \cdot \Delta t^{*}} \cdot \frac{d}{D}
$$

ここで $d$ は気泡直径、 $k$ は物質移動係数、 $L$ は界 面長さ、 $c_{\infty}$ は遠方の濃度 $(=0) 、 c_{\text {int }}$ は界面における 溶存濃度、 $\Delta S$ は時間間隔 $\Delta t$ * における気泡面積の 減少量をあらわす。Fig. 3 に、シャーウッド数の 時間変化を示す。図中の実線は、本計算結果とほ ぼ同じレイノルズ数、ペクレ数 $P e$ の条件で推奨 された、以下の経験式[30]である。

$$
S h=\frac{2}{\sqrt{\pi}}\left(1-\frac{2.89}{R e^{1 / 2}}\right)^{1 / 2} P e^{1 / 2}
$$

図より、最初はやや高い值を予測しているが、そ の後は経験式によく一致していることがわかる。

以上の結果を踏まえ、本シミュレーション法は おおむ放妥当であると結論付けた。以下、実現象 では気泡を水中に噴出した直後に相当する、濃度 境界層および後流の未発達状態を議論する。

\section{2 下降流中の対称軸上気泡}

初期に $R e=1000$ の下降流中の対称軸上に置か れた気泡の場合について、代表的な 2 時刻におけ る二酸化炭素濃度分布を、白黒コンター図として Fig. 4 に示す。図中の黒色は飽和濃度域を、白色 は濃度 0 の領域を示す。グレースケールの数值の 単位は $\mathrm{mol} / \mathrm{m}^{3}$ である。

Fig. 4(a)の $t=0.04 \mathrm{~s}$ では、気泡から溶け出し た二酸化炭素は、気泡頂部から界面に沿って濃度 境界層を形成した。気泡下部で合体した境界層か ら、後流中に線状の高濃度領域が発生した。

Fig. 4(b) の $t=0.08 \mathrm{~s}$ では、後流中央を下方に 伸びる高濃度域のほかに、気泡の左右から対称に 2 本の曲線状の高濃度域が現れた。これは境界層 内の高濃度域がはく離せん断層によって輸送さ れた結果である。

Fig. 4(c) の $t=0.16 \mathrm{~s}$ では、はく離せん断層の 変動に対応して高濃度域が分断されている。これ は二酸化炭素の拡散・吸収を促進する。この結果 は StohrらのpH感応PLIF 法を用いた静止水中を 上昇する二酸化炭素気泡の結果[31] 一一致する。

\section{3 下降流中のオフセット気泡}

Fig. 5 に、Re=1000の下降流中のオフセット気 泡の場合について、4 時刻における二酸化炭素濃 度分布を白黒コンター図により示寸。Fig. 4 と同 様に、グレースケールの数值の単位は $\mathrm{mol} / \mathrm{m}^{3}$ 、 黒色は飽和濃度域を、白色は濃度 0 の領域を示寸。

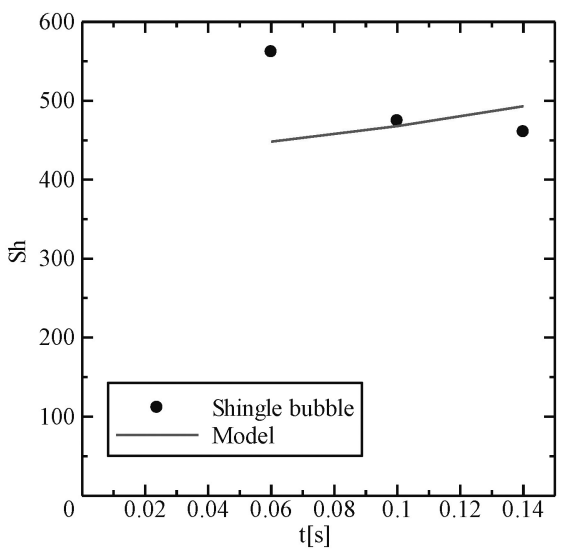

Fig. 3 Sherwood number as a function of time.

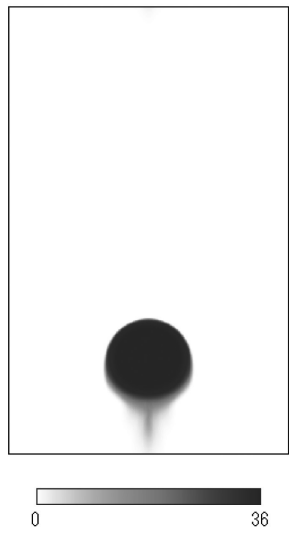

(a) $t=0.04 \mathrm{~s}$

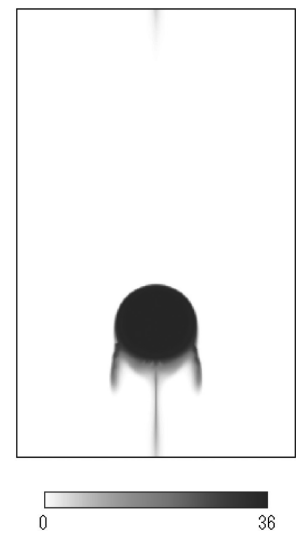

(b) $t=0.08 \mathrm{~s}$

(c) $t=0.16 \mathrm{~s}$

Fig. $4 \mathrm{CO}_{2}$ concentration field in the case of a bubble on the axis. 


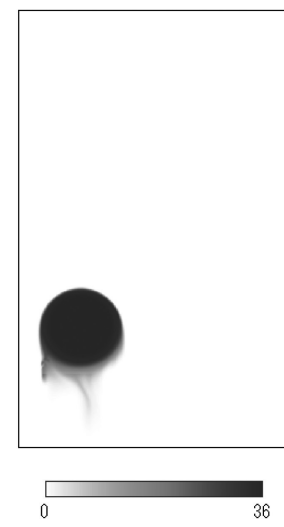

(a) $t=0.04 \mathrm{~s}$

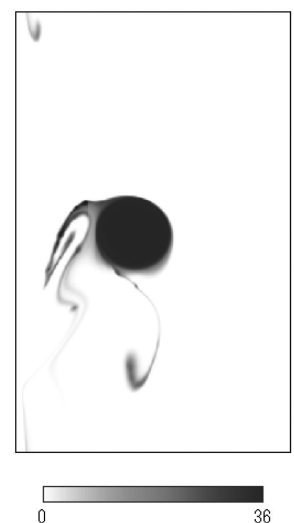

(c) $t=0.12 \mathrm{~s}$

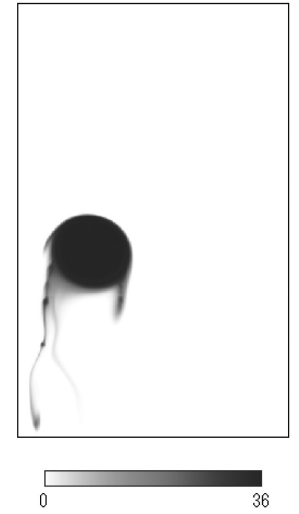

(b) $t=0.08 \mathrm{~s}$

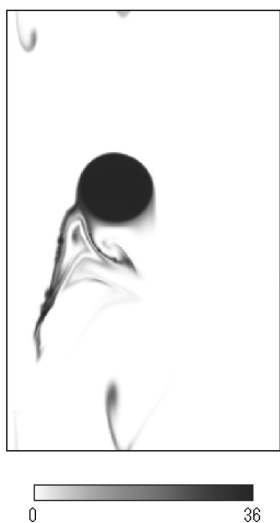

(d) $t=0.16 \mathrm{~s}$

Fig. $5 \mathrm{CO}_{2}$ concentration field in the case of an offset bubble.

気泡の初期位置が左壁に近いので、気泡左側の 圧力が右側のそれより高くなり、はく離せん断層 を含む後流の発達は非対称になる（Figs. 5(a), 5(b) 参照)。その結果、右方向の揚力が顕著にな り、気泡は上昇しつつ $t=0.08 \mathrm{~s}$ 時点より右方向 に移動する。Fig. 5(c) では、左側の優勢なはく離 せん断層により多量の二酸化炭素が拡散してい る。また、Fig. 5(b)に見られるはく離せん断層に より形成された濃度域が、右側下部に観察される。

Fig. 5(d) では、気泡が対称軸に近づき、かつ 気泡頂部付近に自身の後流が接近するため、左方 向の揚力が生じて、気泡は上昇しつつ $t=0.12 \mathrm{~s}$ 時点の位置から左方向に移動し始める。同時に、 気泡後流のせん断層のはく離位置が気泡下部に 移動するとともに、後流はその領域がより広がり、 かつその構造がより複雑になる。このような後流 の変化によって、二酸化炭素の拡散と吸収が強化
されたと結論できる。

\section{4 下降流速度の影響}

Fig. 6 には、気泡等価直径の時間変化のレイノ ルズ数依存性を示す。Figs. 6(a), 6(b) は、それぞ れ対称軸上気泡の場合、オフセット気泡の場合の 結果である。図からを、から気泡等価直径の時間 変化のレイノルズ数依存性を示寸。Fig. 6 には、 気泡等価直径の時間変化のレイノルズ数依存性 を示す。両図とも、レイノルズ数が高いほど、気 泡径の減少はゆっくりであり、水流により二酸化 炭素の溶解が抑えられたことを表わす。これは、 高レイノルズ数流れによる界面の変形や流れの 変動が、二酸化炭素を後流に輸送するせん断層の はく離を抑制するからである。

図の右端である $t=0.16 \mathrm{~s}$ の值を両図で比較す ると、静止水では対称軸上の場合のほうがオフセ ットの場合よりも気泡径が小さい。これは壁に近 いせん断層が未発達なためである。対照的に、下 降流ではオフセットの場合のほうが対称軸上の 場合よりも気泡径が小さいことがわかる。これは、

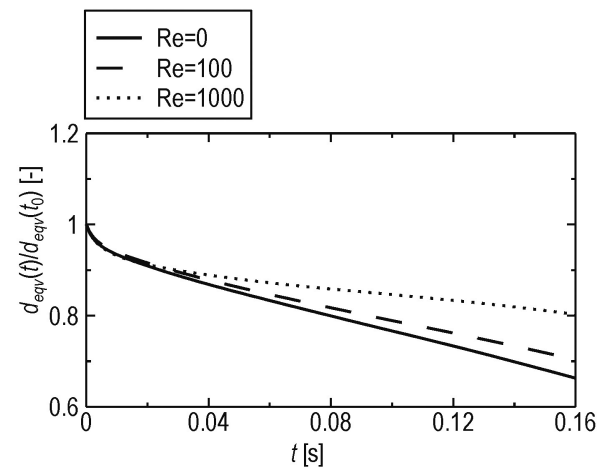

(a) in the case of a bubble on the axis

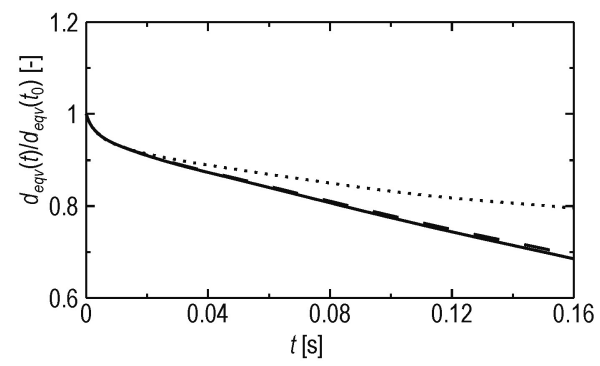

(b) in the case of an offset bubble

Fig. 6 Time change in the bubble equivalent diameter as a function of Reynolds number. 


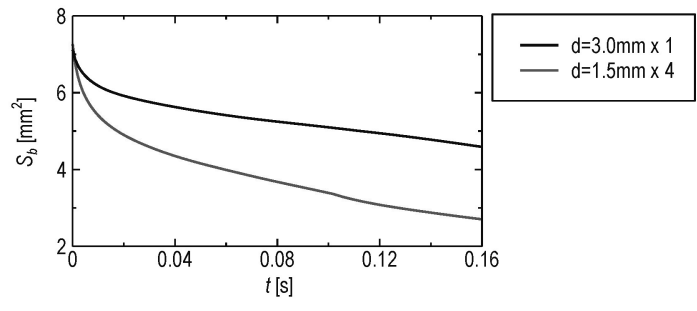

Fig. 7 Comparison of bubble area for quad bubbles with that of a single bubble.

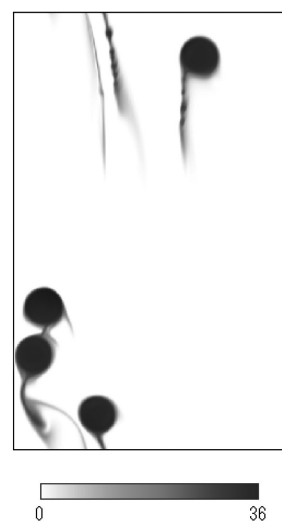

(a) $t=0.08 \mathrm{~s}$

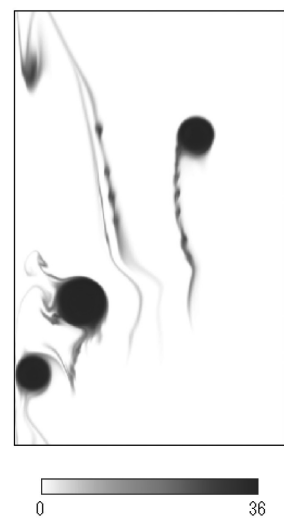

(c) $t=0.12 \mathrm{~s}$

Fig. $8 \mathrm{CO}_{2}$ concentration field in the case of four bubbles.

下降流により気泡の横方向の移動が促進され、後 流がより変動して拡散が促進されるためである。

\section{5 下降流中の四気泡}

初期における気体面積すなわち気体質量が同 一の条件のもと、Re $=1000$ の下降流中の気泡 4 個の気泡体積の時間変化と、3.2 節の気泡 1 個の 気泡体積の時間変化とを比較する (Fig. 7 参照)。
Fig. 7 より、1 気泡の場合よりも 4 気泡の場合の ほうが、気体の減少率が高いことがわかる。気泡 数が増えたことにより、溶解に寄与する界面長さ （したがって界面面積）が二倍に増えたことが、 この高い減少率の原因の一つである。さらに、 $t \approx$ $0.10 \mathrm{~s}$ において、気体の減少がより著しくなった。

Fig. 8 に、上述の気体減少率が変わる時刻の前 後における、二酸化炭素濃度分布を白黒コンター 図により示す。Figs. 4, 5 と同様に、グレースケ 一ルの数值の単位は $\mathrm{mol} / \mathrm{m}^{3}$ 、黑色は飽和濃度域を、 白色は濃度 0 の領域を示す。

Fig. 8(a) において、右側の気泡は、初期より 常に下降し続けた。これは、気泡が小さく気泡に はたらく浮力が弱いためである。したがって、気 泡と液流との速度差は上昇気泡に比べて少なく、 明確なはく離せん断層を伴う後流は確認できな かった。

対照的に、Fig. 8(a) の左側の 2 つ気泡は、対 称軸上の気泡との間を流れる高速の主流の影響 を受けて、下降しながらも左壁方向に移動した。 壁近傍では主流が遅いために、気泡運動は上昇に 転じた。このとき、上側の気泡の後流によって下 側の気泡への液体の接近速度が低下し、下側の気 泡の上昇速度が増加する。そのため、2つの気泡 が接近しやすくなる。

Fig. 8(b) では、左の 2 つの気泡は接触直前で ある。この直後に 2 つ気泡は合体し、界面が変 動した。この界面変動により、界面近傍の水が擋 拌され、二酸化炭素濃度場が変動した。その後、 Fig. 8(c) に見られるように、合体してできた大き な気泡が右方向に移動する際に、濃度境界層や後 流の変動が生じた。これらの因子が二酸化炭素の 拡散を促進したので、Fig. 7 において、4 気泡の 減少がより進んだ。

\section{4. 結 言}

二酸化炭素気泡を含む鉛直チャネル内下降ポ アズイユ流の二次元数值シミュレーションを実 行した。GPUを用いて、連続の式、NS 式、二酸 化炭素濃度の支配方程式、および phase-field 変数 の時間発展方程式を同時に解いた。得られた主な 結果は、以下の通りである。

（1）静止水中を上昇する二酸化炭素気泡の体積減 少割合の予測結果は、実験結果よりも著しい。 この際の要因はいくつか考えられるが、初期 
における濃度場と速度場の違いが主たる要因 のひとつである。また、シャーウッド数の予 測結果は、経験式結果とよく一致した。

（2）単一オフセット気泡の場合、後流の非対称な 発達によって壁から離れる方向の揚力が強ま り、気泡はその方向に移動する。このとき壁 側の優勢なはく離せん断層により、二酸化炭 素が拡散する。その後、自身の後流の影響に より、壁側へ移動する。このとき、後流の領 域がより広がって構造がより複雑になる。こ の後流の変化により、二酸化炭素の拡散と吸 収が促進された。

（3）気泡径の時間減少率は、流速の増加とともに、 よりゆるやかになった。

(4) 総質量が単一気泡の質量と等しい 4 気泡の場 合には、 4 気泡の質量減少率は単一気泡のそ れより高い。4 気泡の総界面長さが単一気泡 のそれよりも長いからである。さらに、気泡 質量の減少は気泡合体により促進された。

\section{謝 辞}

本研究は、日本学術振興会 科学研究費補助金 挑戦的萌芽研究(23656149) および基盤研究 (A) (15H02220) のもとで行われた。本研究の実施に あたり、京都工芸繊維大学の高木知弘准教授より 貴重なご意見を頂いた。ここに記して謝意を示す。

\section{Nomenclature}

a : gradient coefficient

c : concentration

D : diffusion coefficient

$d \quad$ : bubble equivalent diameter

$f \quad$ : energy density function

$g \quad$ : gravitational acceleration

$K \quad$ : Henry's law constant

$k \quad$ : mass transfer coefficient

$L \quad$ : interface length

$M \quad$ : mobility

$N \quad$ : grid number

$P \quad$ : pressure

$P e \quad$ : Peclet number

$p \quad$ : gradient function

$R \quad$ : gas constant

Re : Reynolds number

Sh : Sherwood number

$T$ : temperature $t \quad$ : time

$\vec{u}$ : velocity vector

$[\mathrm{m} / \mathrm{s}]$

$v_{m}$ : molar volume

$\left[\mathrm{m}^{3} / \mathrm{mol}\right]$

$W \quad$ : energy barrier

$x, y$ : Cartesian coordinate

$[-]$

[m]

\section{Greek letters}

$\gamma \quad$ : interface energy

$\Delta S \quad$ : decrease in bubble area

$\left[\mathrm{J} / \mathrm{m}^{2}\right]$

$\Delta t$ : time increment

$\left[\mathrm{m}^{2}\right]$

$\Delta t^{*}$ : time interval

[s]

[s]

$\Delta x, \Delta y:$ grid resolution

[m]

$\delta \quad$ : interface thickness

[m]

$\mu \quad$ : viscosity

$v \quad:$ kinematic viscosity

$[\mathrm{Pa} \cdot \mathrm{s}]$

$\left[\mathrm{m}^{2} / \mathrm{s}\right]$

$\rho \quad:$ density

$\sigma \quad:$ surface free energy

$\left[\mathrm{kg} / \mathrm{m}^{3}\right]$

$\phi \quad$ : phase field variable

$\left[\mathrm{J} / \mathrm{m}^{2}\right]$

\section{Subscripts}

$\begin{array}{ll}\text { gas } & \text { : gas phase } \\ \text { liq } & : \text { liquid phase } \\ \text { sat } & \text { : saturated state }\end{array}$

\section{参考文献}

[1] D'Alessandro, D. M., Smit, B. and Long, J. R., Carbon Dioxide Capture: Prospects for New Materials, Angewandte Chemie Int. Ed., Vol. 49, 6058-6082 (2010).

[2] Takemura, R. and Yabe, A., Rising Speed and Dissolution Rate of a Carbon Dioxide Bubble in Slightly Contaminated Water, J. Fluid Mech., Vol. 378, 319-334 (1999).

[3] Abe, S., Nozawa, S., Hosokawa, S. and Tomiyama, A., Bubble Dissolution of $\mathrm{CO}_{2}$-water Two phase Bubbly Flows in a Vertical Pipe (in Japanese), Progress in Multiphase Flow Research, Vol. 2, 9-16 (2007).

[4] Horikane, K., Yamasaki, R., Mimura, T., Kitagawa, A. and Hagiwara, Y., Interaction Among Rising Bubbles, Falling Adsorption Particles and Downward Water Flow, $8^{\text {th }}$ International Conference on Multiphase Flow, Paper no. ICMF2013-947, 1-5 (2013).

[5] Figueroa-Espinosa, B. and Legendre, D., Mass or Heat Transfer from Spheroidal Gas Bubbles Rising through a Stationary Liquid, Chem. Eng. Sci., Vol. 65, 6296-6309 (2010).

[6] Bothe, D., Koebe, M., Wielage, K. and Warnecke, H.J., VOF-simulations of Mass Transfer from Single Bubbles and Bubble Chains Rising in Aqueous Solutions, Proc. of $4^{\text {th }}$ ASME-JSME Fluids Eng. Conf. paper number FEDSM2003- 45155, 1-7 (2003).

[7] Ezu, Y., Omori, T. and Kajishima, T., Numerical 
Simulation of Flow and Mass Transfer Around Rising Bubbles (in Japanese), Japanese J. Multiphase Flow, Vol. 24, 539-547 (2011).

[8] Hassanvand, A. and Hashemabadi, S.H., Direct Numerical Simulation of Mass Transfer from Taylor Bubble Flow through a Circular Capillary, Int. J. Heat and Mass Transfer, Vol. 55, 59595971 (2012).

[9] Aboulhasanzadeh, B., Thomas, S., Taeibi-Rahni, M. and Tryggvason, G., Multiscale Computations of Mass Transfer from Buoyant Bubbles, Chem. Eng. Sci., Vol. 75, 456-467 (2012).

[10] Ganguli, A.A. and Kenig, E.Y., A CFD-based Approach to the Interfacial Mass Transfer at Free Gas-liquid Interfaces, Chem. Eng. Sci., Vol. 66, 3301-3308 (2011).

[11] Hayashi, K. and Tomiyama, A., Interface Tracking Simulation of Mass Transfer from a Dissolving Bubble, Proc. of ASME-JSMEKSME 2011 Joint Fluids Eng. Conf., paper number AJK2011-04007, 1-9 (2011).

[12] Liu, C. and Shen, J., A Phase Field Model for the Mixture of Two Incompressible Fluids and Its Approximation by a Fourier-spectral Method, Physica D, Vol. 179, 211-228 (2003).

[13] Shu, S. and Yang, N., Direct Numerical Simulation of Bubble Dynamics Using Phasefield Model and Lattice Boltzmann Method, Ind. Eng. Chem. Res., Vol. 52, 11391-11403 (2013).

[14] Takada, N. and Tomiyama, A., Numerical Simulation of Two-phase Flows with Phase Change Using a Phase-field Method (in Japanese), Progress in Multiphase Flow Research, Vol. 2, 173-180 (2007).

[15] Takada, N., Matsumoto, J. and Matsumoto, S. Prediction of Two-phase S lug Flow Patterns in Microchannel with T-junction (in Japanese), Japanese J. of Multiphase Flow, Vol. 28, 32-38 (2014).

[16] Chiu, P.-H. and Lin, Y.-T., A Conservative Phase Field Method for Solving Incompressible Two-phase Flows, J. Computational Physics, Vol. 230, 185-204 (2011).

[17] Tanaka, K., et al. translated, Ball Physical Chemistry (in Japanese), Vol. 1, 126-128, Kagaku Dojin, Kyoto (2004).

[18] Ohsakai, T., Kano, K. and Kuwahata, S. Basic Electrochemistry (in Japanese), 17-18, Kagaku Dojin, Kyoto (2000).

[19] Kinoshita, T., Numerical Simulation on the
Dissolution of Carbon-dioxide Bubbles in Water Using a Phase-field Method Adopted to Graphics Processing Units (in Japanese), Master Thesis, Kyoto Institute of Technology (2015).

[20] Takaki, T. and Yamanaka, A., Phase-field Method -Design of Material Structures by Numerical Simulation- (in Japanese), 23-26, Yokendo Co., Tokyo (2012).

[21] Sun, Y. and Beckermann, C., Phase-field Modelling of Bubble Growth and Flow in a Hele-Shaw Cell, Int. J. Heat Mass Transfer, Vol. 53, 2969-2978 (2010).

[22] Sanders, J. and Kandrot, E., CUDA by Example: An Introduction to General-Purpose GPU Programming, NVIDIA Co. (2010).

[23] Duff, I. S. and Meurant, G. A., The Effect of Ordering on Preconditioned Conjugate Gradients, BIT Numerical Mathematics, Vol. 29, 635-657 (1989).

[24] Kajishima, T., Conservation Properties of Finite Difference Method for Convection (in Japanese). Trans. Japan Soc. Mech. Eng. Ser B., Vol. 60, 2058-2063 (1994).

[25] Kawamura, H., Direct Numerical Simulation of Turbulence by Finite Difference Scheme. The Recent Development in Turbulence Research, 54-60 (New York: Academic Press) (1995).

[26] Yabe, T., Ishikawa, T., Wang, P. V., Aoki, T., Kadota, Y., Ikeda, F., A Universal Solver for Hyperbolic Equations by Cubic-polynomial Interpolation II. Two- and Three Dimensional Solvers, Computer Physics Communications, Vol. 66, 233-242 (1991).

[27] NIST, NIST Reference on Constants, Units and Uncertainty, http://physics.nist.gov/cuu/ (Jan. 7, 2015).

[28] NIST, NIST Chemistry WebBook, http://webbook.nist.gov/chemistry/ (Jan. 7, 2015).

[29] Society for Chemical Engineers, Japan, Kagakukougaku Binran $6^{\text {th }}$ ed. (in Japanese), Maruzen Co., Ltd., Tokyo (1999).

[30] Clift, R., Grace, J.R. and Weber, M.E., Bubbles, Drops, and Particles, 135-137, Dover Publishing Inc., Mineola (2005).

[31] Stohr, M., Schanze, J. and Khalili, A., Visualization of Gas-liquid Mass Transfer and Wake Structure of Rising Bubbles Using PH-sensitive PLIF, Exp. in Fluids, Vol. 47, 135-143 (2009). 